\title{
THE GEOPOLITICAL CONTEXT OF CHAMORRO CULTURAL PRESERVATION IN GUAM, U.S.A.
}

\author{
Maria-Elena D. Diaz \\ University of Oklahoma
}

The island of Guam shares with many Pacific islands, and other areas with indigenous people, a history of foreign encroachment, population devastation and renewal as well as political, economic, and cultural transformations in the context of the development of the capitalist global economy in the modern-world system (e.g. Carrano and Sanchez 1965; Sanchez 1988; Kame'eleihiwa 1992; Rogers 1995; Trask 1999; Wallerstein 2004). Guam is about 209 square miles, 33 miles long, and 12 miles at its widest point (Bureau of Labor Statistics 2009). The nearness of Asia gives this American territory a strong Eastern influence through the people and products that make their way to this small, but geopolitically important location almost eight hours from Hawaii and three hours from the Philippines by air travel. Surviving near annihilation under Spanish rule, brutal Japanese occupation during World War II, and American liberation that further devastated then modernized the island, the Chamorro people (the descendants of the indigenous inhabitants of the island who also identify as Guamanian) ${ }^{1}$ have been largely patriotic to the United States since before the United States Congress passed the Organic Act in 1950, which granted island residents American citizenship. The largest and most southern of the Mariana Islands in the western Pacific Ocean, Guam serves as the commercial and military hub of Micronesia today, one of three cultural regions along with Polynesia and Melanesia that comprise Oceania (Carrano and Sanchez 1965; Rogers 1995; Warheit 2010).

In the last quarter of the twentieth century, Chamorros lost their majority status in the island, as non-Chamorros residents began to outnumber Chamorros. Moreover, a large diaspora, outnumbering Chamorros in Guam, lives in the United States mainland today (Bureau of Statistics and Plans 2012b). Under American rule, immigration from Micronesia and Asia has brought together people from many diverse cultures that now make their home in Guam. Some arrive with financial resources, American cultural capital-including English skills and higher education; others arrive with very little, including limited or no English

1 For the sake of clarity, "Guamanian" will be used in this paper to refer to residents of Guam, while "Chamorro" will be used to refer to descendants of the indigenous island people. 
skills. In addition to the impact on the local infrastructure and economy, this influx of peoples brings multiple cultural orientations simultaneously into the island community. A major military build-up has begun to accommodate the eventual removal of United States military troops from Okinawa (Conerly 2014). While Chamorros are generally supportive of United States military needs, many are concerned about the ramifications of these activities to the indigenous culture and people (Harden 2010; Warheit 2010; Weaver 2010a,b). Outside of Guam and some United States military families, most Americans continue to be unaware of this homeland of the Chamorro people due to its small size and relative isolation up until World War II. Since then, Guam has become an increasingly important United States military strategic location that provides access to Asia, and is often referred to as "the tip of the spear" (Sanchez 1988; Department of Interior 2014). United States foreign policy, including the current development of Guam as a forward base in the Pacific, greatly impacts island residents and constrains efforts toward Chamorro self-determination and cultural preservation. This article provides a case study of Guam through a broad survey of historical influences on the indigenous Chamorro culture, a description of the island's contemporary multicultural diversity, and a consideration of some of the current geopolitical and socioeconomic challenges to Chamorro culture in the place "where America's day begins."2

\section{Historical Influences on Chamorro Culture in Guam ${ }^{3}$}

\section{Indigenous Chamorros}

Ancient Chamorros, the indigenous people of Guam, are believed to be descended from seafaring people from Southeast Asia who migrated to the islands perhaps as far back as 1500 B.C. In the pre-European contact era, the local economy was self-sustaining through farming and fishing, and Chamorros lived abundantly off the land and sea. Ancient Chamorros practiced communal systems of land tenure, worshiped the spirits of their ancestors, and revered the natural environment. Ancient Chamorro society was matrilineal, with kinship ties and land ownership traced through women, and afforded women a prominent role in their families and communities. Indigenous women were attributed with protecting the culture, perpetuating the language, and preserving a Chamorro identity through the centuries (Carrano and Sanchez 1965; Sanchez 1988; Rogers 1995; Political Status Education Coordinating Commission [PSECC] 1996).

2 Refers to Guam's location as the most western point of the United States, situated on the western side of the International Date Line.

3 Detailed histories of Guam include: Thompson 1947; Carrano and Sanchez 1964; Sanchez 1988; Rogers 1995. 
The basic unit of social organization was families or clans. Islanders lived in villages, several of which constituted a district. Each district was administered by a council of village leaders. Within a gendered division of labor, women played a dominant role in the home, and highranking women participated in governing district councils. Thus, highranking women wielded power and were treated with deference and respect (Carrano and Sanchez 1965; Sanchez 1988; Rogers 1995; PSECC 1996).

Central to Chamorro culture during this era was a set of values that constituted inafa'maolek, a way of living that continues to inform contemporary Chamorro culture (Sanchez 1988; PSECC 1996; Pacific Daily News December 25, 2011). Integral to inafa'maolek is the belief that people need to be good to each other to live happily and in harmony. Therefore, showing respect to each other, elders, and leaders is highly valued, along with respect for ancestors and nature. Chamorros are expected to be generous with each other and visitors, and to provide assistance, or chenchule', during celebrations and times of crises (Sanchez 1988). To be greedy is considered to be tai mahmah'lao, or without shame, and indicates a poor upbringing (PSECC 1996). Kostumbren Chamorro (Chamorro cultural practices) permitted Chamorros in the Mariana Islands to live in relative harmony. The occasional clan or village conflict that led to violence ended after the loss of just a few fighters (Carrano and Sanchez 1965).

\section{Spanish Influence}

More than 200 years before European landings in the better known Polynesian Islands, such as the Hawaiian Islands, Spanish explorer Ferdinand Magellan landed in Guam in 1521. The arrival of Magellan marked the first European encounter with the Pacific Islands, followed by foreign domination in every island society in Oceania over the next several centuries. Cultural conflict marked encounters between Westerners and Pacific Islanders. For example, as part of inafa'maolek and chenchule', Chamorros shared food and possessions freely, and expected the same from visitors. When Chamorros helped themselves to pieces of iron and a row boat from Magellan's ship, perhaps perceived as reciprocity by the islanders who provided abundantly for the sickly crew upon their arrival, an angry Magellan burned many huts and killed several men. Afterwards, Magellan named the Mariana Islands, Islas de los Ladrones, Islands of Thieves (Sanchez 1988; Rogers 1995).

Guam endured over 300 years of Spanish rule from 1565 to 1898 (Carrano and Sanchez 1965; Rogers 1995). As the largest of the Mariana Islands chain, Guam was the center of Spanish colonization in the Pacific. More than a century would past after laying claim to Guam before 
Spanish administrators began to actively colonize the island (Sanchez 1988). Lying along the trade route between Mexico and the Philippines, the island initially was a source of provisions for occasional Spanish traders, and then later European whalers and other ships passing through the Pacific Ocean (Carrano and Sanchez 1965; Rogers 1995). Occasionally, Carolinians, another Micronesian people, also visited Guam's shores for trade, as they did in the pre-contact era. Nonetheless, these were rare events and Guam remained relatively isolated under Spanish rule.

Early Spanish and other European visitors to the island provided accounts of early Chamorros. The portrayal of the indigenous people varied, depending on the observers and the type of relationship they entered into with Chamorros. Some witnesses described them as sociable, proud, clever, loving, hardworking, playful, and peaceful, with strong physiques and a pleasing appearance (Carrano and Sanchez 1965; Thompson in Sanchez 1988; Rogers 1995). They were observed to raise their children gently-even scolding with loving words, to care for sick family members and neighbors, and to communally build and repair homes. Chamorros enjoyed gathering in their villages for celebrations and feasts, and welcomed those from other villages. Other traders, who believed themselves stuck with the short end of a deal, described them as deceitful. When angered, Chamorros could become vengeful and willing to fight.

The Spanish influence on the Chamorro people was pervasive. The indigenous people learned the Spanish language and incorporated Spanish foods and customs into the Chamorro culture. Another major influence was the introduction of Roman Catholicism (Carrano and Sanchez 1965; Sanchez 1988; Rogers 1995; PSECC 1996). In the age of European exploration, missionaries frequently traveled to unknown lands to convert people to Christianity. In Guam, Jesuit priests, under the leadership of Padre San Vitores, started the first permanent mission in 1668. As efforts increased to convert Chamorros to Christianity and to change more of their customs, Chamorros rebelled. After several decades of fighting to remove the Spanish from Guam, and even longer exposure to Western diseases, Chamorros, especially the men, were nearly annihilated by the end of the seventeenth century. A people of over 50,000 earlier in the century had been reduced to less than 4,000 by 1700 (Carrano and Sanchez 1965; Sanchez 1988).

The Catholic Church gained a prominent role in the religious and cultural practices of Chamorros, providing opportunities for education, language preservation, social cohesion, and the perpetuation of core Chamorro values; an influence which continues today (Sanchez 1988; Rogers 1995). Although limiting the pastoral participation of women, 
the Church promoted family and culture, including the Chamorro language, which may explain its continued influence. Despite not being able to serve as priests, women played prominent leadership roles in church organizations and activities.

During the Spanish era, island women were credited with the preservation of the Chamorro culture and language. High levels of intermarriage with Spaniards, Filipinos, and Mexicans after the ChamorroSpanish wars allowed the Chamorro population to increase overtime and preserve a Chamorro identity - a central component of cultural preservation. Changes to Chamorro culture continued, such as replacing the matrilineal system with the practice of male primogeniture inheritance and assigning children the last names of their fathers. Nonetheless, women remained the primary influence in the home, where the Chamorro language continued to be spoken. Guam's relative isolation from the rest of the world slowed island development, and likely facilitated the preservation of Chamorro culture in the midst of the turbulent transformation to Catholicism and adaptation to Spanish rule. Once the Spanish won the religious battle, Chamorros were generally free to go about their lives of raising their families and tending to their farms (Sanchez 1988; Rogers 1995).

\section{American Influence}

At the end of the Spanish-American War in the late nineteenth century, the possession of Guam was peacefully passed to the United States in the Treaty of Paris of 1898. This meant another culture shock to islanders. United States Naval administrations implemented the Americanization and modernization of the island. English replaced Spanish as the language for official business and education, and improvements were made in healthcare, sanitation, education, and criminal justice (Carrano and Sanchez 1965). Since Guam was not an open port, foreign influence was limited (Rogers 1995). The early years of American rule were a time of cultural adaptation and relative isolation from the larger world community.

Guam's isolation ended with the onset of World War II. Japanese forces in the Pacific invaded Guam on December 8, 1941, and a brutal Japanese occupation ensued for almost three years. In addition to forcing the Japanese language and mandatory labor on the island's residents, the Japanese military established a savage police force whose abusive practices inflicted mental and physical harm, including the wanton murder of islanders, especially near the end of the occupation (Sanchez 1988; Rogers 1995). A devastating invasion by American forces on July 21, 1944, removed the Japanese military and led to the eventual end of the war in the Pacific region. To support the end of the war, the United States Na- 
val Administration on Guam built up the island infrastructure and initiated a new era in Guam.

Major changes occurred in a short time period. The post-war modern age brought in aviation and regular mail service to the island, and the agrarian sustenance economy transformed into a wage economy almost overnight, with office jobs becoming more available and desirable. In island politics, Guam's residents elected thirty-six members to the First Guam Congress in 1946, including Rose T. Aguigui, a Merizo Elementary School teacher (Sanchez 1988). Two years later, she was joined by Mariana L.G. Lujan, another educator, in the Second Guam Congress. By 1950, after several petitions, Guamanians were granted American citizenship, and limited self-governance under the administration of the United States Department of the Interior. The long-standing requirement for a security clearance to travel to Guam was lifted in 1962 by Executive Order in the Kennedy Administration, which opened the island to visitors and business investors. Responding to the repeated requests of Chamorro leaders, the United States permitted the first locally elected governor in 1970; however the island government continued to exercise limited power (Sanchez 1988; Rogers 1995).

The United States federal government and Japanese tourism and business investors boosted the island economy throughout the second half of the twentieth century. Business activity increased through the entrepreneurial activities of Chamorros, Americans, and Japanese. This fueled an explosion in growth and development, peaking in the late 1980s, followed by a worldwide recession in the early 1990s, and recurring fiscal problems into the new century influenced in part by global and American economic conditions. These dynamics transformed island life in one generation from predominantly rural villages with a strong bartering system into a cash-oriented and debt-burdened society with a strong island culture (Sanchez 1988; Rogers 1995).

\section{Politics and Cultural Preservation}

Chamorros have continually requested an improvement in their political relationship with the United States throughout American rule, desiring increased self-governance and an equal role in determining the future of the island (Sanchez 1988; Rogers 1995). In 1960, the United Nations General Assembly adopted the Declaration on the Granting of Independence to Colonial Countries and People (Resolution 1514 [XV]) that stated that all people and all nations have the equal right to selfdetermination. Guam is one of sixteen non self-governing territories remaining on the United Nations list, and thus remains a colony, subject to the wishes of the United States (Tolentino 2009b). Consequently, there is a sense among many Chamorros that Guamanians are second-class 
American citizens, since they don't have an equal voice in the American polity compared to state governments or even compared to other Micronesian islands (Warheit 2010; Harden 2011).

During the era of liberation movements in the United States in the 1970s, Chamorro rights activists expressed their concern about the oppression of Chamorro culture and loss of political power and land (Rogers 1995; Tolentino 2009a). In the 1980s, activists succeeded in bringing the question of Guam's political status to the attention of Chamorro residents. Starting in 1988, island leaders submitted the Guam Commonwealth Act to Congress multiple times, and ended up being denied each time. Ironically, an earlier 1975 United States federal inter-agency task force report recommended this political status for the island, which the Department of Interior kept hidden from island leaders (Willens and Ballendorf 2008). However, several issues, such as control of the land, immigration, and military expansion, blocked progress in negotiations on commonwealth status, as did federal concerns over allowing only Chamorros to vote on the island's political status (Quimby 2009). For Chamorros, this was an obvious affront to their right to self-determination, as articulated by the 1960 United Nations resolution on decolonization, in order to protect United States military interests in the region. Federal authority in Guam's political aspirations is a clear indicator of the island's continued colonial status.

Control of land is another contentious issue that continually resurfaces in politics, especially since the federal government controls almost a third of the land (Warheit 2010; Weaver 2010a,b). Moreover, as a United States territory whose value is in national defense, the military can claim additional land in the interests of national security through eminent domain. Today, this is one of many concerns as the residents of Guam, and Chamorros in particular, undergo a United States military build-up. Contemporary geopolitics suggests that the needs of the United States military will continue to dictate the outcome of land disputes, and dominate the outcome of any renegotiation in political status.

Chamorros recognize that in addition to land, language provides a strong foundation for cultural preservation (Perez 2005). Yet, English replaced Chamorro as the main language in the majority of island homes by 1970 (Rogers 1995). Taking steps to counteract the decline of Chamorro language usage, the Government of Guam (GovGuam) made both English and Chamorro the official languages of the island in 1972. Further, a Chamorro language and cultural studies program was introduced into the public education system in the 1970s, championed by Dr. Katherine B. Aguon, Guam's first Chamorro woman to earn a Ph.D. and serve as director of education and vice-speaker of the Guam Legislature (Sanchez 1988; "GovGuam News" 2007). Yet only 43 percent of 
Chamorros, five years of age and older indicate in the 2010 Census that they speak Chamorro in the home (Bureau of Statistics and Plans 2012a). Consequently, recent legislation requires the extension of public school education in Chamorro studies through the tenth grade by the 2014-2015 academic year (Public Law 31-45, Substitute Bill 95-31).

\section{Contemporary Multicultural Diversity}

From the pre-World War II period to the end of the twentieth century, Guam's population grew exponentially. The Chamorro population increased over 300 percent, from about 20,000 to over 65,000 (Chamorros alone and more than one race). In the same period, the total Gaum population grew seven-fold from over 22,000 to almost 155,000 people. Consequently, by 1980 Chamorros no longer represented the majority of island residents, but continued to be the largest ethno-racial group. The breakdown of the population by Chamorros and non-Chamorros from 1940-2010 is provided in the following table.

Table 1. Population Distributions for Guam from 1940-2010

\begin{tabular}{|l|c|c|}
\hline & Chamorros (alone or in combo) & Total Population \\
\hline 1940 & $20,177(91 \%)$ & 22,290 \\
\hline 1960 & $34,762(52 \%)$ & 67,044 \\
\hline $1970 *$ & $47,598(56 \%)$ & 84,996 \\
\hline 1980 & $47,845(45 \%)$ & 105,979 \\
\hline 1990 & $57,648(43 \%)$ & 133,154 \\
\hline $2000^{* *}$ & $65,243(42 \%)$ & 154,805 \\
\hline $2010^{* * *}$ & $69,098(43 \%)$ & 159,358 \\
\hline
\end{tabular}

Source: Table 2: Population of Guam, 1940-1990 (Rogers 1995:273).

* From Sanchez 1988:369. ** From Table DP-01Profile of General Demographic Characteristics for Guam (Guam Department of Commerce 2002). Total represents 57,297 Chamorro alone and 7,946 Chamorro and other combinations. *** From Table GU8: Ethnic Origin or Race (Bureau of Statistics and Plans 2012a). Total represents 59,381 Chamorros alone and 9,717 Chamorros and other combinations.

Asian immigrants, predominantly from the Philippines but also from Korea, China, and Japan, added to the island population throughout the second half of the twentieth century. Many arrived with families to pursue economic opportunities. Part of the growth in population was also due to the signing of the Compacts of Free Association between the United States and the Federated States of Micronesia, the Republic of the Marshalls, and the Republic of Palau in 1986. The Compacts permitted residents of these island-nations free entry to Guam, and many immigrated with their families from these economically depressed island communities (Rogers 1995). 
While Chamorros continue to have a significant island presence, the tremendous changes throughout the twentieth century have led to the development of a multicultural, ethnically diverse society. Among those who reported membership in a single group in the 2010 United States Census, the largest ethno-racial groups in the island population, in decreasing order, are Chamorros $(59,381)$, Filipinos $(41,944)$, and Whites $(11,312)$ (Bureau of Statistics and Plans 2012a). Other Pacific Islanders, predominantly Micronesians from Chuuk (11,230), Palau (2,563), and Pohnpei $(2,248)$, collectively constitute a larger number than Whites; while other Asians-predominantly Koreans $(3,437)$, Chinese $(2,368)$, and Japanese $(2,368)$ - are just slightly smaller in number. The following table shows the population distributions by major racial and ethnic groups.

Table 2: Population Distributions for Major Ethnic and Racial Groups, Guam 2010

\begin{tabular}{|l|c|c|c|c|c|}
\hline & Chamorros & Filipinos & Whites & $\begin{array}{c}\text { Other } \\
\text { Pacific } \\
\text { Islanders }\end{array}$ & $\begin{array}{c}\text { Other } \\
\text { Asians }\end{array}$ \\
\hline Total & $\begin{array}{c}59,381 \\
(69,098 \\
\text { alone and } \\
\text { in combo) }\end{array}$ & 41,944 & 11,321 & 19,201 & 9,437 \\
\hline $\begin{array}{l}\text { \% of total } \\
\text { population }\end{array}$ & $37 \quad(43)$ & 26 & 7 & 12 & 6 \\
\hline
\end{tabular}

Sources: Table GU8 Ethnic Origin or Race (Bureau of Statistics and Plans 2012a).

Note: Total population is 159,358

One indicator of relative ethno-racial harmony in the island is the number of residents who identify as having more than one race. In the 2010 Census, 9 percent of Guamanians identify as having more than one race, compared to the national rate of just 3 percent (Bureau of Statistics and Plans 2012a). Among this subpopulation, 65 percent identify as Chamorro and some other race, and over half identify as Asian and some other race; among Chamorros, the rate is 14 percent (U.S. Census Bureau 2012). A final measure of the island's multiculturalism is language usage in the home. Among those five years of age and older, the majority of all ethno-racial groups, with the exception of Whites and Chamorros (45 percent), speak a language other than English in the home. Thus, Guam's ethno-racial diversity exists in a social context of multiculturalism, where Chamorro and American cultures are the predominant influences and Chamorros remain the largest ethno-racial group. 


\section{Challenges Facing Chamorros}

In the twenty-first century, Chamorros face several challenges that are likely to influence the Chamorro way of life. These include continuing economic instability, the ramifications from immigration due to the Compacts of Free Association, and the United States military build-up. How these challenges are addressed may be critical for Chamorro cultural preservation.

\section{Economic Instability}

Many forces influence the economy of Guam, including macro factors-such as globalization, the strength of the American economy, and American foreign policy - and local factors, especially fiscal management practices and commitment to education quality. While island leaders have little control over macro factors, like the global recession of 2008 (International Monetary Fund 2009), there are issues that island leaders can address to reduce government debt and booster Guam's economy.

As a United States trust territory and strategic military location, Guam's economy has benefitted from infusions of federal monies and projects to maintain a level of military readiness. With most government revenue the result of federal aid and tourism industries (Rogers 1995; Bureau of Labor Statistics 2009), GovGuam has been the largest employer of the civilian population in the modern era. Although the proportion of government has slightly declined in recent decades: In 1980, GovGuam employed 27 percent $(9,056)$ of the civilian workforce (Rogers 1995); in the 2010 Census, this ratio dropped to 24 percent (Bureau of Statistics and Plans 2012a).

In addition to employing a significant proportion of the island population, GovGuam has frequently been accused of living beyond its means. Many island residents have called for an end to chronic government overspending and increased efficiency in the management of resources (e.g. Limtiaco 2011a; Pacific Daily News July 26, 2011, January $29,2014)$. For example, although the current administration claims to have fixed an over $\$ 300$ million deficit, budget problems were addressed with bond-borrowing, which becomes a burden for future generations (Pacific Daily News 2014a). In the meantime, island residents complain about critical shortages in the provision of public services, such as education, healthcare, and public safety, while payments to vendors and even government agencies are often delayed (Daleno 2014; Pacific Daily News 2014a,b). Despite these financial challenges, politicians recently passed pay raises for GovGuam employees during an election year; a political tactic used successfully by another administration in the $1980 \mathrm{~s}$ (Pacific Daily News 2014b). 


\section{Ethno-racial stratification in a dual labor market}

In addition to being perceived as a political bribe - a consequence of across-the-board raises - is an increase in inequality in an already bifurcated economy. The dual labor market divides Guam's workers into the haves and have-nots, with primary sector workers earning good salaries with benefits, and workers in the secondary sector making low wages and struggling to make ends meet. Comparing socioeconomic outcomes across ethno-racial groups reveals an ethno-racial hierarchy of income and educational attainment. On average, Chamorros, Whites, and Filipinos experience higher levels of socioeconomic attainment, while Micronesians have the lowest levels. In the 2010 U.S. Census Guam Cross-Tabulations, the median household income in Guam is $\$ 48,274$. This increases to $\$ 49,327$ for Filipinos, $\$ 50,362$ for Chamorros alone, $\$ 62,389$ for Whites. All other major ethnoracial groups are below the median, and in decreasing order include other Asians $(\$ 46,250)$, Koreans $(\$ 34,955)$, other Pacific Islanders $(\$ 32,994)$, and Chuukese $(\$ 21,427)$.

Human capital models of income attainment generally apply to island patterns of socioeconomic integration: Higher education and English skills are correlated with higher income. Among those 18 years of age and older in the 2010 U.S. Census, 79 percent of Guamanians have high school degrees and 18 percent have a bachelor's degree. Whites have the highest rate of educational attainment: 97 percent have a high school degree and 34 percent have a bachelor's degree. Among Filipinos, 82 percent are high school graduates and 25 percent have a bachelor's degree, while 75 percent of Chamorros are high school graduates and 11 percent have a bachelor's degree. For Koreans and other Asians the comparable rates for a high school degree are 84 percent and 80 percent, respectively, and 20 percent and 25 percent for a bachelor's degree. While the educational attainment rates for other Pacific Islanders drops to 69 percent for a high school degree and 5 percent for a bachelor's degree, only 54 percent of Chuukese have a high school degree, and 2 percent have a bachelor's degree.

The higher than average educational and income attainment rate of Whites is likely due to migration from the continental United States to pursue professional opportunities in the island economy. In addition, Whites constitute 6 percent of the GovGuam workforce and 18 percent of the local federal workforce, both of which provide on average higher pay than private sector jobs (Daleno 2014a). Although Chamorros have education rates lower than Whites, Filipinos, Koreans, and other Asians, they have the second highest household income levels, right behind Whites. Their higher household income levels are likely due to the higher proportion of Chamorros in GovGuam jobs (64 percent of 
GovGuam employees) and federal jobs (42 percent of federal employees). Filipinos, with their above average income and educational attainment rates are also well-represented in government jobs, with 21 percent of GovGuam positions and 21 percent of federal jobs. Among Asians, many likely arrive to the island to fill shortages in professional positions, and with more financial resources than most Pacific Islander immigrants. For both Asians and other Pacific Islanders, limited English skills likely lower household incomes.

Ironically, Chamorros are also well-represented among those at the lower end of the socioeconomic hierarchy. In the 2010 U.S. Census, the poverty rate for all individuals in Guam is 23 percent, and for Chamorros alone is 24 percent. The only ethnoracial groups with higher poverty rates are other Pacific islanders at 41 percent and Chuukese at 63 percent. Whites have the lowest poverty rate ( 8 percent), followed by other Asians (12 percent), Filipinos (14 percent), and Koreans (20 percent). Among those sixteen years of age and older, the island unemployment rate for those seeking work in the civilian labor force is 8 percent in the 2010 Census. Among Chamorros, the unemployment rate is 10 percent, while 23 percent of Chuukese and 13 percent of other Pacific Islanders are also unemployed at rates higher than the island average. Ethno-racial groups with unemployment rates below the island average include Filipinos and Whites at 5 percent, Koreans at 4 percent, and other Asians at 3 percent. In part, the higher than average poverty and unemployment rates for Chamorros may be due to slightly below average levels of educational attainment and a higher reservation wage, the lowest wage a worker would be willing to accept for a particular job. Some Chamorros may prefer to live off the land than work in the secondary sector, and many can rely on extensive family networks to help alleviate some of the most difficult consequences of poverty and unemployment. Nonetheless, clearly not all Guamanians are economically well-off, with some subpopulations experiencing comparatively high rates of poverty and unemployment. This creates a situation whereby some island residents may desire economic growth, whatever the cost, which can pose a challenge to cultural preservation.

\section{Opportunities for Economic Development}

Into the foreseeable future, the largest sources of revenue for the island economy may continue to be federal expenditures and tourism. Federal assistance to the island is likely to continue at high levels, especially in light of the current United States military build-up. Tourism, predominantly from Japan, continues to be promoted with the goal of increasing annual visitors from 1.3 million to 2 million annually in the next six years (Daleno 2014b). While this contributes to the economy, 
most new jobs will be in the low-paying service sector. Beyond this, political leaders are also promoting the island as a good place for investors to many of its neighbors in Asia (Thompson 2011).

Entrepreneurship is a viable option that could be more fully exploited. Ideally, GovGuam's economic stimulus efforts will also include increasing support for small business development programs, with the provision of financial resources and expertise to island residents who can than pursue local business niches, and perhaps even participate in the global market. The potential for increased local entrepreneurship and exports can be supported by the University of Guam and Guam Community College, who play key roles in providing educational instruction to prepare students to be successful in the workforce.

Economic growth and diversification are important to economic health, and players in the today's global economy are well-educated. Continuing commitment to higher education and partnerships with the private sector will provide opportunities for Guam's residents to obtain the skills and knowledge to pursue economic opportunities in the private sector. In order for residents to be prepared to take advantage of economic opportunities, the island community must insist that quality public education-from pre-school through postsecondary education-is available to all capable residents. Education budgets cannot be allowed to become victims of budget deficits.

\section{Impact from Compacts of Free Association}

In the midst of economic challenges in Guam, immigration from Micronesia and Asia is likely to continue, since Guam is the core economy in Micronesia and a gateway to the United States from Asia. The Compacts of Free Association (CFA) signed in 1986 between the United States and other Micronesian nation-states - the Republic of the Marshall Islands (FAS), the Federated States of Micronesia, and the Republic of Palau-fuels immigration to Guam. The number of Micronesian immigrants nearly doubled between 2003 and 2008, from 9,831 to 18,305 (Limtiaco 2011b). In the 2010 Census, other Micronesians are 10 percent of the local population, and make up one-fourth of the foreign-born population on Guam (Bureau of Statistics and Plans 2012a.).

Some come to Guam to pursue an education, and all hope to improve their lives. However, islanders of ten arrive with little human or financial capital, or transferable skills. Over 70 percent of Micronesians report speaking a language other than English at home (Bureau of Statistic and Plans 2012a). Consequently, growth in this population has increased the burden on already strained public services, including education, health care, public safety and social services (Sobeck 2013). 
Although Guam is the most common destination for Micronesian immigrants (Bureau of Statistics and Plans 2012b), federal impact reimbursement for costs from Micronesian immigration has been a fraction of reported expenses. From 2004-2012, the Governor of Guam reported $\$ 559$ million in expenses on services for compact immigrants. Only a fraction of the costs through 2011, about $\$ 119$ million of $\$ 441$ million, has been paid (Sobek 2013). During Congressional discussions of the Compact agreements, concerns about their impact on receiving islands were raised. Consequently, reimbursement at higher rates may be forthcoming as the national economy improves. Some of these infrastructure issues may also be addressed through the military build-up, as local leaders work to mitigate negative or unintended consequences from an increased military presence.

Shortchanging island residents can influence community relations with Micronesian immigrants if these Pacific Islanders are perceived as a burden or a threat, and are marginalized instead of socially integrated in productive ways (Aguirre and Turner 2007). Relatively harmonious ethno-racial relations can shift into ethno-racial conflict in the competition over scarce resources in times of economic uncertainty and relatively high levels of immigration (Olzak 1992). When subpopulations are treated as social outsiders, this contributes to a myriad of social dysfunctions, including ethno-racial conflict, which affect the entire island community (Allport 1979[1954]).

\section{United States Military Build-up}

The Obama Administration's has stated the importance of the Pacific in American foreign policy and its commitment to the Guam military build-up (Feller 2011; Pacific Daily News 2011b; Thompson 2012). This will inject cash into the local economy, increase the island population, and present additional challenges to the people of Guam and the preservation of the Chamorro culture (Harden 2010; Warheit 2010; Weaver 2010a,b). Although the initial agreement between the United States. and Japan to transfer troops out of Okinawa was scheduled to be completed in 2014, the build-up has proceeded more slowly due to a recovering United States economy and local concerns about the buildup's impact on the island community (Daleno 2014c). Now scheduled to be completed by 2018 , the military build-up on Guam will bring about 5,000 Marines and their families, and tens of thousands of workers to the island during infrastructure development (Harden 2010; Weaver 2010a,b; Conerly 2014; Daleno 2014c). Population pressures from an influx of people may create social problems if the growth is not properly and sensitively managed (Harden 2010). Even beyond the social dysfunctions 
that may emerge from a population surge, there are other concerns associated with an increased military presence.

Chief among these concerns include the potential for an increase in crime from a larger military population, especially those of a domestic or sexual nature, but also an increase in property crime from increasing levels of inequality and higher rates of poverty (Lutz and Cristobal 2007; Kirk 2008; Lutz 2010). There are also environmental and health impacts from military activities to consider (Kirk 2008; Lutz 2010; Women for Genuine Security 2010); including the likelihood that Guam becomes a more attractive military target in the case of warfare. Further, imagined or real threats to Chamorro culture from a larger military presence could easily translate into ethno-racial conflicts without attention to the needs and concerns of island residents (Lutz and Cristobal 2007; Women for Genuine Security 2010). Federal, military, and local leaders need to be intentional in creating harmonious relations between military families, personnel, and island residents.

Other considerations include an increasing strain on the island's already overburdened infrastructure. These include the costs of improving the delivery of electricity and water, and the disposal of wastes for a much larger population; as well as the capacity to provide education, healthcare, and public safety with declining budget shortages and increasing government debt (Committee on Energy and Natural Resources 2008; Pincus 2009; Lutz 2010). An increase in the general cost of living, as well as in land prices and housing, will likely be additional outcomes of military expansion (Lutz 2010). On the other hand, an infusion of money through military projects, jobs to support the build-up (although most will be temporary), and the settling in of military families up through 2018 are likely to create opportunities for local residents and funds for government coffers, as some local leaders assert. It is also likely that most of the permanent jobs created by this expansion will be in the lower-paying service sector, which would increase income inequality in the dual labor market of the island, and local elites will benefit the most from military expansion (Lutz 2010). The slowdown may provide island leaders with an opportunity to more thoroughly consider all the likely consequences of becoming a forward base in United States foreign policy and respond accordingly.

\section{Chamorro Culture in the Twenty-First Century}

Despite these multiple challenges, Chamorros have created an infrastructure to promote cultural preservation through island institutions, commitment of resources, and cultural participation. Local institutions play a major role in preserving Chamorro culture in the face of pervasive American influence and high levels of multiculturalism. For example, as 
in the past, the Catholic Church continues to play an important role in cultural preservation, with 85 percent of islanders identified as Roman Catholics (Central Intelligence Agency 1999). The island's year-round village fiestas in honor of patron saints are a good example of how Chamorro cultural values of bringing people together and being good to each other are preserved through the Catholic Church (guampedia.com/ fiestas/).

Cultural participation and commitment of resources to maintaining a Chamorro culture are critical to cultural preservation. Within GovGuam is a Department of Chamorro Affairs, whose mission is the preservation, development and promotion of the Chamorro Heritage of Guam (dca.guam.gov). Some of the divisions of this department include The Chamorro Village, a gathering place for local entrepreneurs and products, including food, crafts, and entertainment representing the Chamorro and other cultures-as well as the Guam Museum, Guam Public Library, and the Guam Council on the Arts and Humanities.

To make information about Guam and Chamorro culture available to island residents and the larger global community, grants from the National Endowment for the Humanities, Guam Preservation Trust, the Bank of Guam, the United States Department of the Interior, Gannett Foundation, Guam Council on the Arts and Humanities Agency and other sources led to the creation of the Guampedia Foundation, Inc., in 2009. The foundation provides an on-line source of information about Guam and Chamorro culture, with over a thousand entries from scholars and community leaders (guampedia.com/).

In addition, the island hosts many festivals and other events to spotlight Chamorro culture, as well as other Asia-Pacific cultures. For example, there is the annual Gupot Fanha'aniyan Pulan Chamoru, also known as the Chamorro Lunar Festival, which showcases Chamorro cultural traditions related to farming and fishing by the cycles of the moon (Aoki 2014). Many of the indigenous peoples of Oceania also come together to support indigenous cultural preservation efforts. An example of this is the Festival of the Pacific Arts, which Guam will be hosting in 2017. This multicultural event, with rotating host locations throughout the region, is offered every four years to support the preservation of traditional Pacific cultures (Pacific News Center 2011).

Further, in United States communities where large numbers of Chamorros settle, such as Hawaii, California, Washington, and Texas, Pacific Islanders hold fiestas and festivals to celebrate Chamorro holidays and share island traditions. The Internet, and sites like Facebook, along with the ease of telecommunication, also makes it possible for the Chamorro diaspora to maintain connections to Guam. These social 
structures within Guam, in the region, and in the continental United States support cultural preservation.

The Chamorro culture has survived through history because of the adaptability of the people during times of transformation initiated by foreign powers. To accommodate change, Chamorros have integrated elements of other cultures, while adhering to core indigenous values. All Guamanians can play a role in perpetuating inafa'maolek in Guam's institutions and families and contributing to the Chamorro way of life. Through intentional efforts to teach and preserve their culture through programs and participation, Chamorros may safeguard their unique cultural identity in the continuing age of American hegemony. This case study of Chamorro cultural transformation and current challenges to cultural preservation contributes to limited research in Chamorro studies and on Pacific Islander Americans. It also informs extant research in indigenous cultural preservation, ethnic studies, ethnic stratification, and contemporary colonialism.

\section{REFERENCES}

Aguirre, Adalberto, Jr. and Jonathan H. Turner. 2010. American Ethnicity: The Dynamics and Consequences of Discrimination, 7th ed. New York: McGraw Hill.

Allport, Gordon W. 1979[1954]. The Nature of Prejudice. 25th ed. Cambridge, MA: Perseus Books.

Aoki, Dance. 2014. Festival promotes Chamorro cultural values. Pacific Daily News, January 27. http://www.guampdn.com/.

Bureau of Labor Statistics. 2009. Guam Statistical Yearbook 2008. Guam Department of Labor, Government of Guam.

Bureau of Statistics and Plans. 2012a. Guam Demographic Profile Summary File. Guam State Data Center.

2012b. Guam Statistical Yearbook. Guam State Data Center.

Carrano, Paul and Pedro C. Sanchez. 1965. A Complete History of Guam. Tokyo: Charles E. Tuttle Co.

Central Intelligence Agency. 1999. "The World Fact Book." www.cia .gov/library/publications/.

Committee on Energy and Natural Resources. 2008. "Military Build-Up on Guam Hearing." 110th Congress, May 1. Washington, DC: Government Printing Office.

Conerly, Michelle. 2014. DOD moving in positive direction in military realignment. Pacific Daily News, February 2. http://www.guampdn .com/. 
Daleno, Gaynor Dumat-ol. 2014a. Economic gap widens - Employer: Private sector workers shoulder GovGuam raise." Pacific Daily News February 5. http://www.guampdn.com/.

—. 2014b. "Tourism goal: 2 million visitors." Pacific Daily News, February 5. http://www.guampdn.com/.

_. 2014c. "Buildup work shows progress." Pacific Daily News January 22. http://www.guampdn.com/.

Department of Interior. 2014. Insular Area Summary for Guam. http:// www.doi.gov/oia/islands/guam.cfm.

Feller, Ben. 2011. Countering China, Obama asserts US a Pacific power. Associated Press, November 16. http://news.yahoo.com/counteringchina-obama-asserts-us-pacific-power-234612474.html.

"GovGuam News." 2007. Government of Guam (February 7). http:// www.guam.gov/.

Guam Department of Commerce. 2002. "Profile of General Demographic Characteristics for Guam: Comparison 1990 and 2000." Hagatna, GU: Government of Guam.

Harden, Blaine. 2010. On Guam, planned Marine base raises anger, infrastructure concerns. Washington Post, March 22. http://www.wash ingtonpost.com/.

International Monetary Fund. 2009. "Global Economic Slump Challenges Policies." http://www.imf.org/.

Kame'eleihiwa, Lilikala. 1992. Native Land and Foreign Desires: Pehea LA E Pono Ai? Honolulu, HI: Bishop Museum Press.

Kelman, Brett. 2011. Audit outlines GovGuam shortfalls. Pacific Daily News, December 20. http://www.guampdn.com/.

Kirk, Gwyn. 2008. Gender and U.S. bases in Asia-Pacific: Violence against women, violation of local autonomy, and contamination of the environment are all part of the U.S. military footprint in Asia. Washington, DC: Foreign Policy In Focus, March 14. http://fpif.org/ gender_and_us_bases_in_asia-pacific/.

Limtiaco, Steve. 2011a. OPA: GovGuam's over spending chronic. Pacific Daily News, July 1. http://www.guampdn.com/.

. 2011b. Compact funds inconsistent. Pacific Daily News. November 16. http://www.guampdn.com/.

Lutz, Catherine. 2010. "US Military Bases on Guam in Global Perspective." The Asia-Pacific Journal, 30:3-10.

and Hope Cristobal. 2007. "Environmental Impact Statement for Military Build-up on Guam." Unpublished paper. Faculty of the 
Watson Institute for International Studies and the Chamorro Studies Association, respectively.

Olzak, Susan. 1992. The Dynamics of Ethnic Competition and Conflict. Stanford, CA: Stanford University Press.

Pacific Daily News. 2011a. Cut costs: Elected officials must ensure next budget is fiscally responsible. Editorial. July 26. http://www.guamp dn.com/.

2011 b. U.S. Under Secretary reaffirms commitment to Guam as Pacific hub. News Update. December 15. http://www.guampdn .com/.

2011c. "Blessing: Christmas in Guam is about community and inafa'maolek." Editorial. December 25. http://www.guampdn.com/.

. 2014a. "Wrong: Spending increases not right; GovGuam can't meet obligations." Editorial. January 29. http://www.guampdn .com/.

. 2014b. "No raised: No salary increases for GovGuam while services still lacking." Editorial. February 2. http://www.guampdn .com/.

Pacific News Center. 2011. Planning For 2016 Festival Of Pacific Arts On Guam Has Already Begun. March. http://www.pacificnewscen ter.com/index.php?option=com_content\&id=12257:-planning-for12th-festival-of-pacific-arts-on-guam-begins-\&Itemid=156.

Perez, Michael. 2005. "Colonialism, Americanization, and Indigenous Identity: A Research Note on Chamorro Identity in Guam." Sociological Spectrum, 25(5):571-591.

Pincus, Walter. 2009. GAO Says Military Expansion Will Tax Guam's Infrastructure. Washington Post. April 12. http://www.washington post.com/.

Political Status Education Coordinating Commission (PSECC). 1996. Chamorro Tradition and Values. Agana, GU.

Quimby, Frank. 2009. "Guam Commonwealth Act”, Guampedia, http:// guampedia.com/guam-commonwealth-act/.

Rogers, Robert F. 1995. Destiny's Landfall: A History of Guam. Honolulu: University of Hawaii Press.

Sanchez, Pedro C. 1988. Guahan Guam: The History of Our Island. 1st ed. Agana, GU: Sanchez Publishing House.

Sobek, Angela. 2013. Office of Insular Affairs, "2013 Compact Impact Analysis-Report to Congress." http://ww.doi.gov/oia/reports/. 
Thompson, Erin. 2011. Calvo's Asian trade missions very successful. Pacific Daily News, October 31. http://www.guampdn.com/.

2012. Defense budget bill cuts funds for build-up. Pacific Daily News, January 2. http://www.guampdn.com/.

Thompson, Laura. 1947. Guam and Its People. New Jersey: Princeton University Press.

Tolentino, Dominica. 2009a. "Chamorro Quest for Self-Determination." Guampedia, http://guampedia.com/chamorro-quest-for-self-determi nation/ .

- 2009b. "Commission on Decolonization," Guampedia, http:// guampedia.com/commission-on-decolonization/.

Trask, Haunani-Kay. 1999. From a Native Daughter: Colonialism and Sovereignty in Hawaii. Honolulu: University of Hawaii Press.

U.S. Census Bureau. 2012. "The Two or More Races Population, 2010." 2010 Census Briefs, C2010BR-13. Washington, D.C.

Wallerstein, Immanuel. 2004. World-Systems Analysis: An Introduction. Durham, NC: Duke University Press Books.

Warheit, Vanessa. 2010. The Insular Empire: America in the Mariana Islands. New Day Films.

Weaver, Teri. 2010a. Guam residents voice concerns about military's expansion plans. Star and Stripes, January 11. http://www.stripes .com/.

2010b. "Locals question military's plan to acquire more land on Guam." Star and Stripes, January 28. http://www.stripes.com/.

Willens, Howard P. and Dirk A. Ballendorf. 2008. The Secret Guam Study. Mangilao, GU: University of Guam.

Women for Genuine Security. 2010. Halt the Guam Build up plans: Rewrite the DEIS. April Newsletter. http://www.genuinesecurity.org 